Journal of Clinical Investigation
Vol. 41, No. 3,1962

\title{
THE METABOLIC DEFECT RESPONSIBLE FOR URIC ACID STONE FORMATION *
}

\author{
By PHILIP H. HENNEMAN, $\nmid$ STANLEY WALLACH $\ddagger$ AND ELEANOR F. DEMPSEY \\ (From the Department of Medicine, Massachusetts General Hospital, and Harvard Medical \\ School, Boston, Mass.)
}

(Submitted for publication July 22, 1960 ; accepted November 9, 1961)

The composition of a urinary tract stone often may be related to increased urinary concentration of one or more of the stone constituents or to characteristic hydrogen ion concentrations in the urine (1). Thus calcium phosphate and calcium oxalate are the major constituents of stones in patients with hypercalciuria, cystine stones are limited to patients with increased urinary cystine due to cystinuria (2), and calcium magnesium ammonium phosphate stones are generally found in patients with constantly alkaline urine due to ureasplitting infections. Boyce and King (3) have suggested that formation of an organic matrix may be the primary abnormality in stone formers and that the mineral content of the stone may reflect merely the chemical composition of the urine at the time the matrix was formed. This paper concerns studies of certain chemical factors in patients known to form uric acid stones.

Uric acid stones occurred in 10 per cent of a series of 207 stone patients (1). As a group these patients presented certain clinical characteristics. Thus, of 67 consecutive uric acid stone patients, the average age was 59 , which is considerably older than the average age of the other groups of stone patients (1). Of these 67 patients 42 were male and 15 female. Fifty per cent of this series was Italian or Jewish, in contrast to 14 per cent Italian or Jewish among 77 miscellaneous stone patients for whom no cause of stone was identified (1). Uric acid stones have the same radiodensity as soft tissues, are unapparent in plain roentgeno-

* These studies were supported in part by grants from the American Cancer Society (E-67), the United States Public Health Service (A-605), and Ayerst Laboratories. The material of this paper was published in abstract form under the same title and authors (J. clin. Invest. 1958, 37, 901).

f Present address: Seton Hall College of Medicine, Medical Center, Jersey City 4, N. J.

$\ddagger$ Present address: State University of New York, Downstate Medical Center, Brooklyn, N. Y. grams, and can be demonstrated only by suitable contrast pyelography. The urinary sediment of uric acid stone patients frequently contains uric acid crystals.

\section{METHODS}

The methods for complete balance studies and for chemical determinations have been described previously (4-6). Uric acid was measured both colorimetrically (7) and by a specific uricase method (8). Urinary $\mathrm{pH}$ was sometimes measured with glass electrodes and sometimes estimated colorimetrically with Nitrazine paper. ${ }^{1}$ Urine was refrigerated during 24-hour collections and until analyzed but was not collected under oil. All patients were free of significant urinary tract infection during studies.

\section{RESULTS AND INTERPRETATIONS}

1. Serum and urinary uric acid. At least three subgroups of uric acid stone patients are recognized. In one series (1) of 22 uric acid stone patients 7 were hyperuricemic owing to gout or to polycythemia and some of these hyperuricemic patients had increased urinary uric acid (Figure 1). Chronic diarrhea was present in a second subgroup of 3 patients. Finally, in 14 patients there was no history of gout or chronic diarrhea; 10 of these so tested had normal serum uric acid levels; and none of the 6 so tested had increased urinary uric acid (Figure 1). For the remainder of the paper attention is focused on the biochemical abnormalities characteristic of the majority of uric acid stone patients who did not have diarrhea, gout, hyperuricemia, or hyperuriciuria.

2. Urinary acidity. The average urinary $\mathrm{pH}$ measured by Nitrazine paper of multiple random

\footnotetext{
1 Urinary $\mathrm{pH}$ determinations with Nitrazine paper are reported herein to the nearest $0.5 \mathrm{pH} U$. However, comparisons with glass electrodes generally confirmed the manufacturer's recommendation that for urinary measurements $0.2 \mathrm{pH} \mathrm{U}$ be subtracted from the apparent $\mathrm{pH}$.
} 


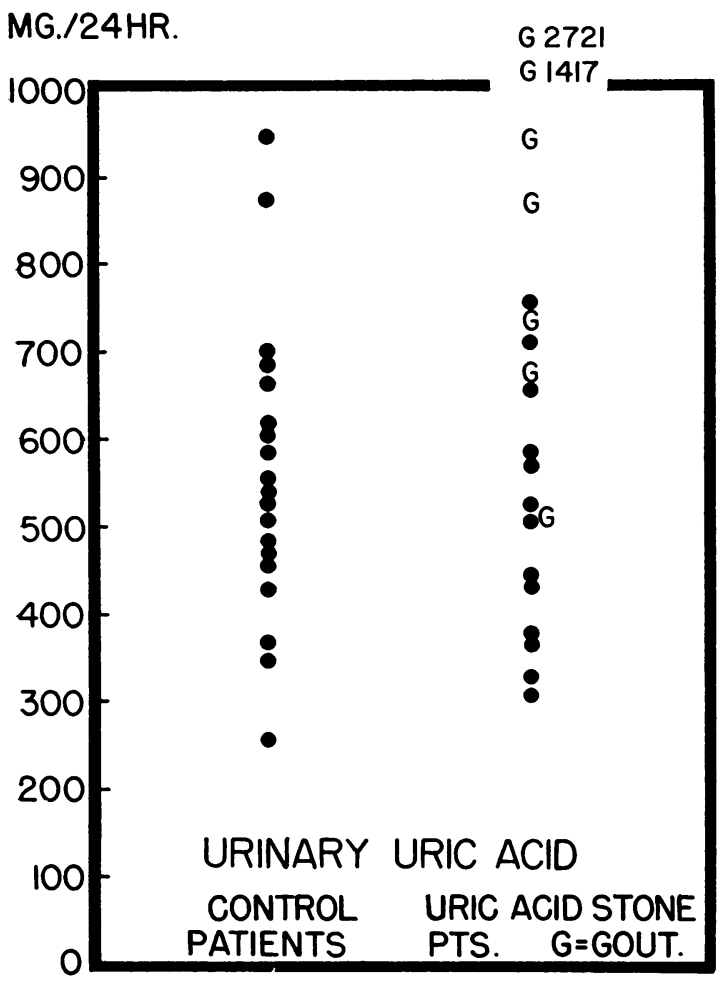

Fig. 1. Urinary Uric acid excretion of 19 control PATIENTS, 7 PATIENTS WITH GOUT AND URIC ACID STONES, AND 13 NORMOURICEMIC URIC ACID STONE PATIENTS. UriC acid values for the uric acid stone patients with known gout are represented by the letter G. Each value for the normouricemic uric acid stone patients and the miscellaneous unselected control patients is represented by a dot. All values were obtained on free diets. Concentrations of urinary uric acid were also similar in the control patients and in the uric acid stone patients. Atsmon and associates (9) have also reported that many uric acid stone patients have normal serum and urinary uric acid values.

fresh voidings throughout the day of 16 uric acid stone patients varied from 4.4 to 5.1 with an overall average of 4.8. Elliot, Sharp and Lewis (10) have recorded that the $\mathrm{pH}$ of similar multiple random voidings of normal persons varied from 4.8 to 7.4 , with an over-all average of 5.9 .

The importance of low urinary $\mathrm{pH}$ in determining precipitation of uric acid is suggested by the estimates of Peters and Van Slyke (11) that the solubility of total uric acid in dilute buffer solutions decreases from 1,580 to $80 \mathrm{mg}$ per $\mathrm{L}$ as the $\mathrm{pH}$ is decreased from 7.0 to 5.0. It is clear from Figure 1 that even normal values for urinary uric acid excretion, when applied to normal urine volumes, imply concentrations far in excess of the predicted solubility at low but not at higher urine pH's.

3. Balance data on uric acid stone patients. Complete balance studies were carried out in four uric acid stone patients. The results of a 9-day complete balance study in a 76 year old Jewish housewife with multiple uric acid stones are typical and are shown in Figures 2 and 3. Urinary $\mathrm{pH}$ estimated with Nitrazine paper at each voiding

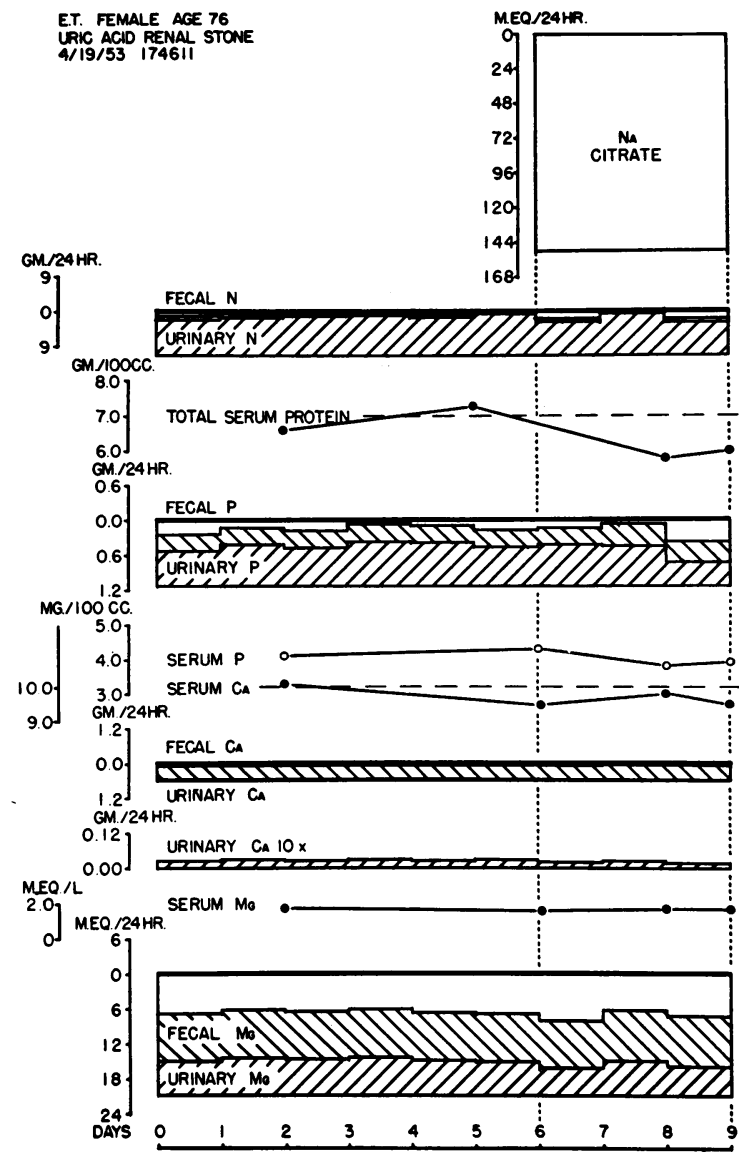

Fig. 2. Balance data for nitrogen, phosphorus, CAlCIUM, AND MAgNesidm on E.T., A 76 year old JewISH HOUSEWIFE WITH URIC ACID RENAL STONES. The patient was on a nearly neutral ash diet for 5 days before and throughout the study. Balance studies in three other uric acid stone patients showed no overt disturbance of nitrogen, phosphorus, or magnesium balance. For each constituent measured there is a heavy zero line and intake is measured down from this line. Urinary and fecal excretion are charted up from the intake line. The scales represent the ratio of these substances as found in most tissues (4). Serum samples were obtained after a 15hour fast. 


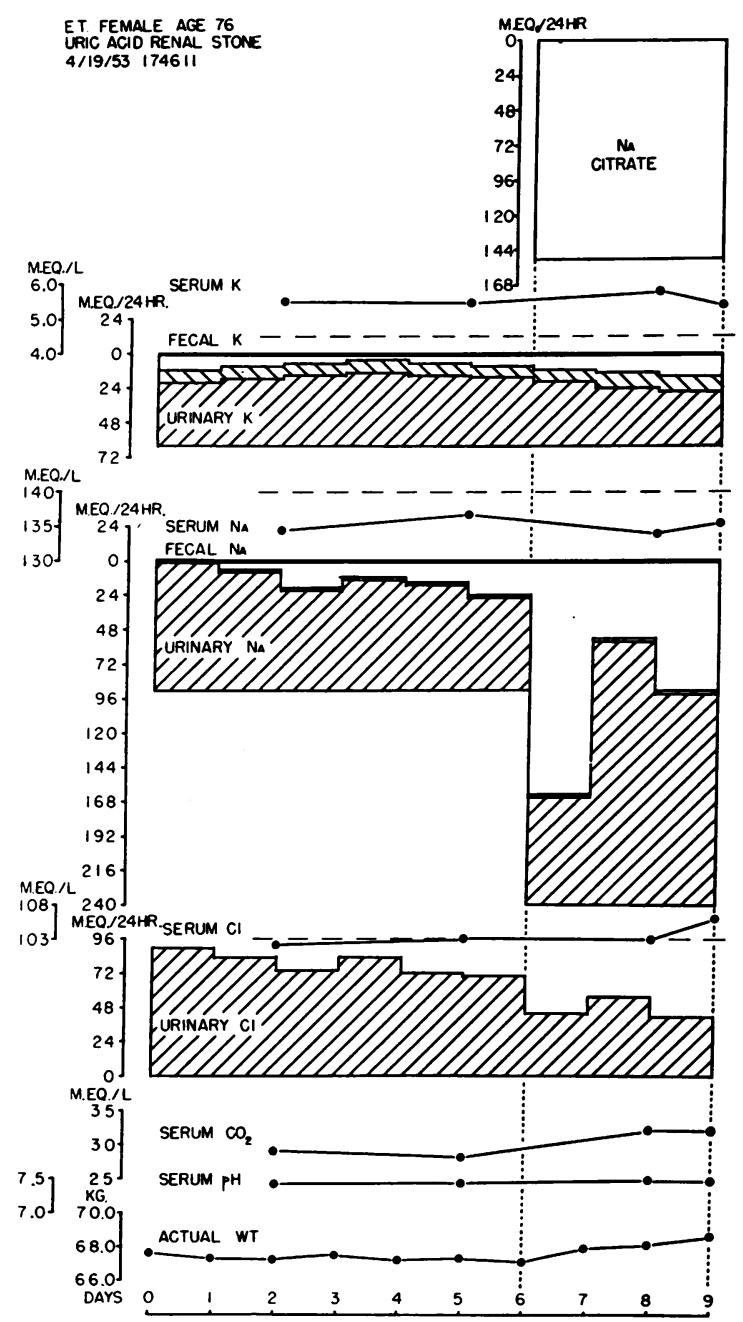

Fig. 3. Balance data Regarding potassium, SOdiUm, CHLORIDE, SERUM $\mathrm{CO}_{2}$ AND PH, AND BODY WEIGHT IN E.T. Fecal and dietary chloride were not measured and hence only urinary chloride is charted. Balance studies in three other uric acid stone patients revealed no overt disturbance of potassium or sodium balance, urinary chloride, or serum $\mathrm{CO}_{2}$ and $\mathrm{pH}$.

was regularly 4.5 to 5.5 with only two values as high as 6.0. The constant marked acidity of the urine on a nearly neutral ash diet excluded racial selection of a strongly acid ash diet as the cause for constant marked urinary acidity. Normal venous blood $\mathrm{pH}, \mathrm{CO}_{2}$, and major electrolytes excluded systemic acidosis as a cause for an acid urine. There was no evidence of renal insufficiency as judged by normal urinalysis, fasting blood nonprotein nitrogen, urinary concentration, urinary culture, and excretion of phenolsulfon- phthalein. The possibility that clinically unapparent fecal bicarbonate loss led to compensatory acid urine in the "idiopathic" uric acid stone formers, as it does in those with chronic diarrhea, was made unlikely by the finding of normal (6) fecal $\mathrm{Na}, \mathrm{K}$, $\mathrm{Ca}$, and $\mathrm{Mg}$. Normal serum $\mathrm{K}$ and $\mathrm{CO}_{2}$ values excluded significant potassium deficiency. Since sodium balance showed only the usual 12 to 24 $\mathrm{mEq}$ daily positive balance attributable to normal (but unmeasured) sweat sodium, it is unlikely that there were excessive sweat sodium losses.

Figure 4 presents data regarding the major urinary anions and cations of Patient E.T. The average daily urinary organic acid excretion of 36

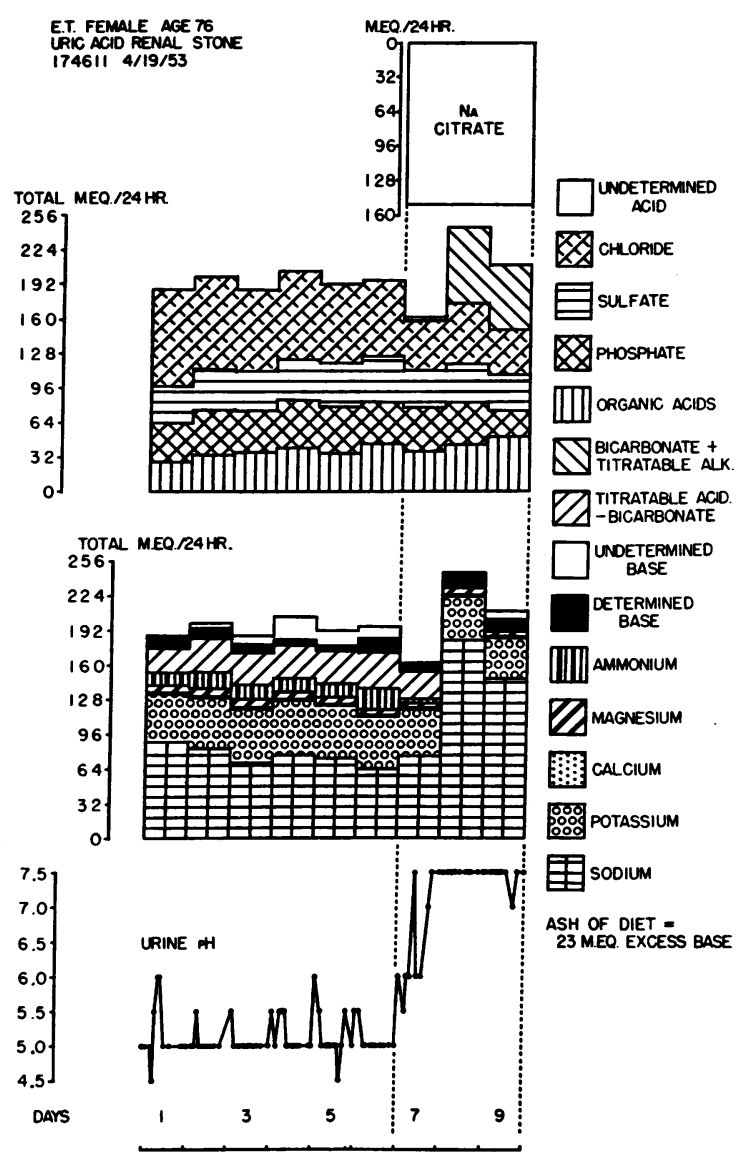

Fig. 4. Sum of urinary anions and cations of E.T. The value for urinary ammonium is approximately onehalf that for $\mathrm{TA}-\mathrm{CO}_{2}$. If titratable acidity per se had been measured it would have been even greater than $\mathrm{TA}-\mathrm{CO}_{2}$. Note the constantly very acid urine (estimated with Nitrazine paper at each voiding) with a mean value less than $\mathrm{pH}$ 5.5. Sodium citrate alkalinized the urine in normal fashion. 
TABLE I

Average values for urinary $p H$, ammonia, titratable acidity minus bicarbonate and uric acid, and serum bicarbonate after 6 days on constant nearly neutral ash diets in four patients with uric acid stones*

\begin{tabular}{|c|c|c|c|c|c|c|}
\hline Patient & Age & $\begin{array}{l}\text { Urine } \\
\text { pH }\end{array}$ & $\begin{array}{l}\text { Urine } \\
\mathrm{NH}_{4}^{+}\end{array}$ & $\begin{array}{c}\text { Urine } \\
\mathrm{TA}-\mathrm{CO}_{2}\end{array}$ & $\begin{array}{l}\text { Urine } \\
\text { Uric acid }\end{array}$ & $\underset{\mathrm{HCO}_{2}-}{\text { Serum }}$ \\
\hline & yrs & $U$ & $\begin{array}{l}m E q / \\
24 \text { hrs }\end{array}$ & $\begin{array}{l}m E q / \\
24 \text { hrs }\end{array}$ & $\begin{array}{l}m g / \\
24 \mathrm{hrs}\end{array}$ & $m E_{q} / L$ \\
\hline $\begin{array}{l}\text { E.T. } \\
\text { A.A. } \\
\text { I.Y. } \\
\text { J.P. }\end{array}$ & $\begin{array}{l}76 \\
66 \\
60 \\
62\end{array}$ & $\begin{array}{l}5.0 \\
5.6 \\
5.2 \\
5.5\end{array}$ & $\begin{array}{l}15 \\
22 \\
14 \\
25\end{array}$ & $\begin{array}{l}30 \\
34 \\
30 \\
25\end{array}$ & $\begin{array}{l}449 \\
486 \\
405 \\
700\end{array}$ & $\begin{array}{l}29 \\
33 \\
29 \\
32\end{array}$ \\
\hline
\end{tabular}

* Balance data for nitrogen, phosphorus, calcium, sodium, and potassium in these patients were normal. Peters and Van Slyke (12) list normal daily urinary ammonium as 20 to $70 \mathrm{mEq}$. The above average values for E.T. and I.Y. fall below and those of A.A. and J.P. lie at the lower limits of this normal range.

$\mathrm{mEq}$ is in the normal range (13) of 0.6 to 1.0 $\mathrm{mEq}$ per $\mathrm{kg}$ body weight per day (which for this $55 \mathrm{~kg}$ patient would mean a value between 33 and $55 \mathrm{mEq}$ per day). Urinary total organic acid excretion was also unremarkable in uric acid stone patients A.A., I.Y., and J.P. Balance data for nitrogen, phosphorus, calcium, sodium, and potassium were normal in three additional uric acid stone patients.

After reviewing the above data Schwartz and Relman (14) pointed out that normally in very acid 24-hour urine specimens the milliequivalents of ammonium $\left(\mathrm{NH}_{4}^{+}\right)$exceed those of titratable acidity (TA), whereas Patient E.T. with uric acid stones excreted less than half as many milliequivalents of $\mathrm{NH}_{4}{ }^{+}$as of TA. ${ }^{2}$ Table I illustrates similar findings in three other uric acid stone patients. In Figure 5 the urinary $\mathrm{NH}_{4}^{+}: \mathrm{pH}$ relationship found in the four uric acid stone patients is compared with similar values reported for normal subjects reported by Milne, Stanbury and Thomson (16).

4. Response to ammonium chloride. Table II illustrates that three normal subjects were able to increase excretion of titratable acidity, ammonium, and calcium sufficiently within 6 days to meet the metabolic challenge of a moderate daily load of ammonium chloride. The less adequate response of two uric acid stone patients is also shown. Due to the low $\mathrm{pH}$ of the urine of the uric acid

2 Due to the technical difficulty of preventing loss of $\mathrm{CO}_{2}$ by aeration from 24-hour urine specimens and, as discussed elsewhere (15), the measurement of titratable acidity minus bicarbonate $\left(\mathrm{TA}-\mathrm{CO}_{2}\right)$ was used in these studies rather than measurement of $\mathrm{TA}$ and $\mathrm{CO}_{2}$ separately. stone patients in the control period further increase in titratable acidity was limited, and the increase in ammonium was inadequate to match the acid load within 6 days. As a consequence, systemic acidosis was more marked than in the normal subjects.

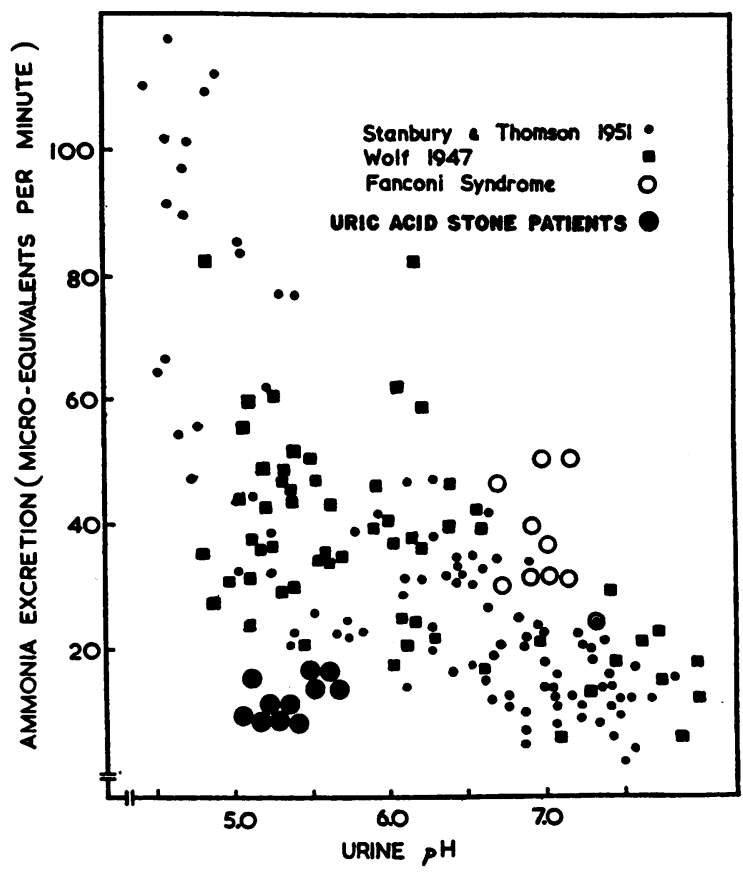

Fig. 5. The Relationship of PH ANd $\mathrm{NH}_{4}^{+}$IN URINe OF FOUR PATIENTS WITH URIC ACID STONES AS COMPARED WITH NORMAL SUBJECTS. [Reprinted with additions by permission of Milne, Stanbury and Thomson (16).] The data for normal subjects reported by Milne and coworkers were based on urinary collections of brief duration. The age of these control subjects was not reported. The data of the uric acid stone patients represent 24hour collections. 
TABLE II

Urinary $p H$, ammonium, titratable acidity minus bicarbonate, and calcium during constant nearly neutral ash diets before and after 5 and 6 days of $\mathrm{NH}_{4} \mathrm{Cl}$ administration to three normal subjects and to two patients with uric acid stones*

\begin{tabular}{|c|c|c|c|c|c|c|c|c|c|c|c|}
\hline \multirow[b]{2}{*}{ Subjects } & \multicolumn{5}{|c|}{ Control period for average urinary: } & \multirow{2}{*}{$\underset{\text { load }}{\mathrm{NH}_{4} \mathrm{Cl}}$} & \multicolumn{5}{|c|}{ Average, Days 5 and 6, $\mathrm{NH}_{4} \mathrm{Cl}$} \\
\hline & $\mathrm{pH}$ & $\mathrm{NH}_{4}{ }^{+}$ & $\mathrm{TA}-\mathrm{CO}_{2}$ & $\mathrm{Ca}$ & Sum & & $\mathrm{pH}$ & $\mathrm{Ca}$ & $\mathrm{NH}_{4}+$ & $\mathrm{TA}-\mathrm{CO}_{2}$ & Sum \\
\hline & $U$ & \multicolumn{4}{|c|}{$m E q$ per 24 hours } & $m E q C l / d a y$ & $U$ & \multicolumn{4}{|c|}{$m E q$ per 24 hours } \\
\hline S.W., NC & 5.7 & 42 & 33 & 3 & 78 & 148 & 5.1 & 11 & 157 & 53 & 221 \\
\hline P.N., NC & 6.1 & 30 & 20 & 5 & 55 & 148 & 5.4 & 13 & 152 & 35 & 200 \\
\hline L.C., NC & & 32 & 7 & 3 & 42 & 130 & & 9 & 116 & 45 & 170 \\
\hline I.Y., UAS & 5.2 & 14 & 30 & 3 & 47 & 143 & 4.9 & 9 & 103 & 39 & 151 \\
\hline J.P., UAS & 5.5 & 25 & 25 & 3 & 53 & 148 & 5.0 & 10 & 125 & 42 & 177 \\
\hline
\end{tabular}

The "sum" columns refer to the sum of the milliequivalents of $\mathrm{NH}_{4}+, \mathrm{TA}-\mathrm{CO}_{2}$ and calcium. The increase in this sum approaches the chloride load in the normal subjects. The uric acid stone patients were unable to increase ammonium excretion to a similar degree and consequently had a more marked dislocation of serum bicarbonate and chloride. The control subjects were 28,23 , and 25 years old; I.Y. was 60 , and J.P. was 62 . NC = normal controls; UAS = uric acid stones.

\section{DISCUSSION}

The above findings suggest that constant marked acidity of the urine is an important factor in uric acid stone formation. Of the various possible defects that could maintain such constant marked urinary acidity, decreased renal tubular secretion of ammonium was probably present in all four uric acid stone patients; all of these patients showed urinary ammonium less than titratable acidity, lower ammonium to $\mathrm{pH}$ ratios than those reported during brief urine collections in normal subjects, and less capacity to increase ammonium after an acid load than did three normal young subjects. Urinary ammonium, titratable acidity, and $\mathrm{pH}$ have not been measured or reported in a large series of control subjects of similar age on nearly neutral ash diets. It should be noted that the uric acid stone patients were 60 to 76 years old (Table I). Hilton. Goodbody and Kruesi (17) have shown that elderly subjects have a decreased ability to restore blood $\mathrm{pH}$ and $\mathrm{CO}_{2}$ to normal during prolonged ammonium chloride administration. Thus it is possible that deficient ammonium excretion is typical of aging and, when especially marked, may contribute to uric acid stone formation. The defect in ammonium secretion in the uric acid stone patients was incomplete and did not result in systemic acidosis on diets that were not strongly acid ash.

The findings in 10 of 18 uric acid stone patients of unusually low urinary calcium (less than 60 mg per 24 hours) despite normal serum calcium also suggests a disturbance of renal tubular func- tion. The increased incidence in Italian and Jewish patients suggests a congenital factor in uric acid stone formation.

We have not carried out similar studies on hyperuricemic uric acid stone patients but have observed a constantly very acid urine in several such patients in contrast to the normal variation in urinary $\mathrm{pH}$ in several gouty patients without known uric acid stone formation. The higher incidence of uric acid stones in gouty patients than in the general population suggests that the disturbance of ammonium secretion may somehow be related to a disturbance of uric acid metabolism, but the relationship is not apparent in the many normouricemic, normouriciuric uric acid stone patients.

Uric acid stones occur in patients with chronic diarrhea. It is suggested that excessive fecal bicarbonate and potassium loss in such patients may result in constantly low urinary $\mathrm{pH}$ with resultant uric acid precipitation.

The chemical characteristics of the uric acid diathesis include a constantly very acid $(\mathrm{pH} 4.5$ to 5.5) urine without systemic acidosis and a low 24-hour urinary ammonium which is less than titratable acidity. The diagnosis is established if uric acid stones are recovered from the patient. It should be noted that normal individuals may produce similar urine but probably do not do so for prolonged periods. The chronic administration of sodium citrate or of any alkali in quantities sufficient to raise the urinary $\mathrm{pH}$ above 6.0 prevents uric acid stone formation. 


\section{SUM MARY}

Uric acid renal stones may occur in hyperuricemic, hyperuriciuric gouty patients but more often occur in elderly Italian or Jewish patients with normal serum and urinary uric acid levels. Precipitation of uric acid in such patients is probably due to the constant marked acidity of their urine. In four such patients the marked acidity was associated with a low ammonium excretion; two patients showed increases in ammonium excretion after acid loading which were less than those observed in three normal young subjects.

\section{REFERENCES}

1. Melick, R. A., and Henneman, P. H. Clinical and laboratory studies of 207 consecutive patients in a kidney-stone clinic. New Engl. J. Med. 1958, 259, 307.

2. Harris, H., and Warren, F. L. Quantitative studies on urinary cystine in patients with cystine stone formation and their relatives. Ann. Eugen. (Lond.) 1953, 18, 125.

3. Boyce, W. H., and King, J. S. Crystal-matrix interrelations in calculi. J. Urol. (Baltimore) 1959, $81,351$.

4. Reifenstein, E. C., Jr., Albright, F., and Wells, S. L. The accumulation, interpretation, and presentation of data pertaining to metabolic balances, notably those of calcium, phosphorus, and nitrogen. J. clin. Endocr. 1945, 5, 367.

5. Dawson, J., Dempsey, E., Bartter, F., Leaf, A., and Albright, F. Evidence for the presence of an amphoteric electrolyte in urine of patients with "renal tubular acidosis." Metabolism 1953, 2, 225.

6. Dempsey, E. F., Carroll, E. L., Albright, F., and Henneman, P. H. A study of factors determining fecal electrolyte excretion. Metabolism 1958, 7, 108.

7. Folin, O. An improved method for the determination of uric acid in blood. J. biol. Chem. 1930, 86, 179.

8. Praetorius, E., and Paulsen, H. Enzymatic determination of uric acid, with detailed directions. Scand. J. clin. Lab. Invest. 1953, 5, 273.

9. Atsmon, A., Frank, M., Lazebnik, J., Kochwa, S., and de Vries, A. Uric acid stones: A study of 58 patients. J. Urol. (Baltimore) 1960, 84, 167.

10. Elliot, J. S., Sharp, R. F., and Lewis, L. Urinary pH. J. Urol. (Baltimore) 1959, 81, 339.

11. Peters, J. P., and Van Slyke, D. D. Quantitative Clinical Chemistry. vol. 1, Interpretations, 2nd ed. Baltimore, Williams \& Wilkins, 1946, p. 953.

12. Idem. p. 887.

13. Peters, J. P., and Van Slyke, D. D. Quantitative Clinical Chemistry, vol. II, Methods. Baltimore, Williams \& Wilkins, 1932, p. 647.

14. Schwartz, W. B., and Relman, A. S. Personal communication.

15. Albright, F., Burnett, C. H., Parson, W., Reifenstein, E. C., Jr., and Roos, A. Osteomalacia and late rickets: The various etiologies met in the United States with emphasis on that resulting from a specific form of renal acidosis, the therapeutic implications for each etiological sub-group, and the relationship between osteomalacia and Milkman's syndrome. Medicine (Baltimore) 1946, 25, 399.

16. Milne, M. D., Stanbury, S. W., and Thomson, A. E. Observations on the Fanconi syndrome and renal hyperchloraemic acidosis in adults. Quart. J. Med. 1952, 21, 61.

17. Hilton, J. G., Goodbody, M. F., Jr., and Kruesi, O. R. The effect of prolonged administration of ammonium chloride on the blood acid-base equilibrium of geriatric subjects. J. Amer. Geriat. Soc. 1955, 3, 697. 